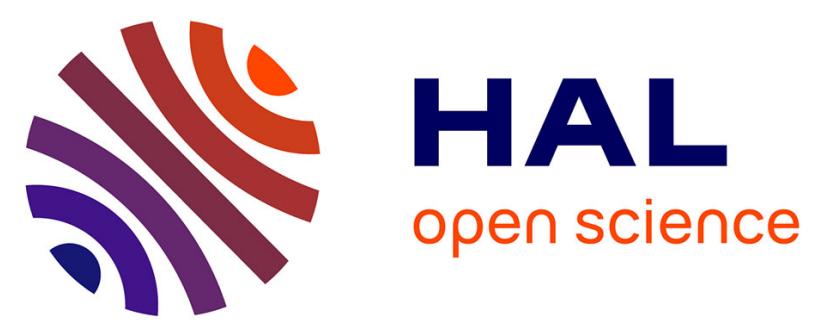

\title{
A multidisciplinary study of the emplacement mechanism of the Qingyang-Jiuhua massif in Southeast \\ China and its tectonic bearings. Part II: Amphibole geobarometry and gravity modeling
}

Wei Wei, Guillaume Martelet, Nicole Le Breton, Yonghong Shi, Michel Faure, Yan Chen, Quanlin Hou, Wei Lin, Qingchen Wang

\section{To cite this version:}

Wei Wei, Guillaume Martelet, Nicole Le Breton, Yonghong Shi, Michel Faure, et al.. A multidisciplinary study of the emplacement mechanism of the Qingyang-Jiuhua massif in Southeast China and its tectonic bearings. Part II: Amphibole geobarometry and gravity modeling. Journal of Southeast Asian earth sciences, 2014, 86, pp.94-105. 10.1016/j.jseaes.2013.09.021 . insu-01005623

HAL Id: insu-01005623

https://hal-insu.archives-ouvertes.fr/insu-01005623

Submitted on 9 Jul 2014

HAL is a multi-disciplinary open access archive for the deposit and dissemination of scientific research documents, whether they are published or not. The documents may come from teaching and research institutions in France or abroad, or from public or private research centers.
L'archive ouverte pluridisciplinaire HAL, est destinée au dépôt et à la diffusion de documents scientifiques de niveau recherche, publiés ou non, émanant des établissements d'enseignement et de recherche français ou étrangers, des laboratoires publics ou privés. 


\title{
A multidisciplinary study of the emplacement mechanism of the Qingyang-Jiuhua massif in Southeast China and its tectonic bearings. Part II: Amphibole geobarometry and gravity modeling
}

- Wei Wei ${ }^{\text {abcde }}$

- Guillaume Martelet ${ }^{\mathrm{d}}$

- Nicole Le Breton ${ }^{\text {bcd }}$

- Yonghong Shi ${ }^{\mathrm{f}}$

- Michel Faure bcd $^{\text {bc }}$

- Yan Chen ${ }^{\text {bcd }}$

- Quanlin $\mathrm{Hou}^{\mathrm{a}}$

- Wei Lin ${ }^{\mathrm{e}}$

- Qingchen Wang ${ }^{\mathrm{e}}$

\section{Highlights}

Geobarometry work shows that the studied massif intrudes into shallow crustal depth. Gravity modeling shows that the massif vertically or sub-vertically intruded.

NE-SW tension gashes as magma conduits imply a syn-emplacement NW-SE regional extension.

\begin{abstract}
The Late Mesozoic geology of the Lower Yangtze area is characterized by extensional sedimentary basins, numerous granitic plutons and several world-class ore deposits. Regionaly, the coeval tectonic and geodynamic framework remains inadequately investigated. In order to provide a more comprehensive understanding of the regional tectonic context, we performed a multidisciplinary study of the emplacement mechanism of the Qingyang-Jiuhua massif. It consists of the granodioritic Qingyang and the monzogranitic Jiuhua plutons, $\mathrm{U}-\mathrm{Pb}$ dated at $142 \pm 1.0 \mathrm{Ma}$ and $131 \pm 2.6 \mathrm{Ma}$, respectively. Biotite and amphibole cooling ages are 5-8 myr younger. Results deduced from field structural observation, petrographic and magnetic fabrics, paleomagnetism show that this massif was probably vertically emplaced by permissive intrusion coeval with weak regional extension. However, detailed information on the characteristics of this tectonic event and its emplacement depth was not documented. Therefore, we carried out an investigation of amphibole geobarometry and gravity modeling in order to address the emplacement mode of the plutons within their regional tectonic framework. Amphibole data show that the Qingyang-Jiuhua massif was emplaced in the upper crust at a depth between 5 and $12 \mathrm{~km}$. Gravity modeling indicates that the massif is laccolithic. It is characterized by several NE-SW-striking linear thickening zones that we interpret as the feeder roots of the massif. These results led us to conclude that (1) the Qingyang-Jiuhua massif was fed by vertical, NE-SW striking tension gashes; (2) consequently the late Early Cretaceous tectonics in the study area was characterized by NWSE extension.
\end{abstract}




\section{Keywords}

- South China;

- Late Mesozoic extension;

- $\mathrm{Al}^{\text {total }}$ in amphibole geobarometry;

- Gravity modeling

\section{Introduction}

As a part of the South China Block (SCB), the Lower Yangtze area experienced similar Cretaceous tectonics as the SE part of SCB, namely: granitic pluton emplacement, continental extensional sedimentary basins' opening, and ore deposits formation (e.g. Gilder et al., 1991, Goodell et al., 1991, Li et al., 2010a, Mercier et al., 2007 and Mao et al., 2011). Numerous geochronological and geochemical studies have been performed in order to illustrate the evolution and provenance of these igneous activities. Now it is well accepted that most of the Early Cretaceous magmatism took place between $145 \mathrm{Ma}$ and $120 \mathrm{Ma}$ (Wu et al., 2012) with a wide diversity of geochemical characters, namely I type, A type and adakitic signatures (Ling et al., 2009 and Wu et al., 2012). However, the understanding of the geodynamic context of the pluton emplacement remains problematic. It was at first interpreted as the result of the thinning of a previously thickened crust (Zhang et al., 2008), from $>50 \mathrm{~km}$, as suggested by the presence of adakites (Wang et al., 2006), to the present $30 \mathrm{~km}$, as documented by seismic reflection data (Schmid et al., 2001). However, Ling et al. (2009) argued that the hypothesis of a previously thickened crust was not consistent with the development of extensional basins during the Late Jurassic to Cretaceous (Ling et al., 2009). Furthermore, the presence of adakites can alternatively be explained by fractional crystallization of mantle-derived magmas within a normal crust (Li et al., 2009a). In the Lower Yangtze area, the NW-SE striking igneous belt is perpendicular to the subduction zone and the symmetric distribution of the A-type and adakite zones relative to the axis of this igneous belt: a slab window model was consequently proposed (Ling et al., 2009). But this model also faces the problems of the synchronous formation of the adakitic rocks and the development of rift basins in the whole Lower Yangtze area (Li et al., 2010a). Based on the arc-affinity of the REE and the trace element distribution patterns of plutons, it has been also proposed that the Lower Yangtze area corresponded to a back-arc environment (Xu et al., 2010).

Compared to the abundance of geochemical work, the structural data are rare and only performed in a few localities with ductile deformation. Consequently, the regional tectonic context of the Cretaceous magmatism is still under dispute. For instance, according to the structural analysis conducted in the Lushan and Dabie massifs, it is argued that a NW-SE extension took place during the early Cretaceous (Lin et al., 2000 and Faure et al., 2003). This feature is interpreted as the initial stage of the steep subduction of the Paleo-Pacific slab (Zhu et al., 2010a). Based on quartz $c$-axis preferred orientation, a NE-SW extension direction was also proposed for the same Cretaceous period ( Zhu et al., 2010b). Because of the disparity of these models, more investigations are needed to clarify the regional tectonic context during the Early Cretaceous. For this purpose, we propose to study plutons contemporaneous of this period, which are good markers of the crustal deformation.

In a Part I twin paper (Wei et al., 2014), we have documented the Early Cretaceous Qingyang-Jiuhua massif with structural observations, Anisotropy of Magnetic Susceptibility (AMS) measurements and paleomagnetism. The results obtained indicate that the emplacement of the granitic massif did not alter the preexisting structure of the country rocks, as fold axes were not modified by the emplacement of the massif. Ductile deformation 
developed only locally at the boundary between the massif and its country rocks. The AMS fabric, characterized by a vertical or sub-vertical foliation near the pluton boundary, and a horizontal or sub horizontal one in the center of the massif, only recorded the magma flow. The scattered AMS lineation did not record any syn-emplacement regional deformation. The paleomagnetic pole of the Qingyang-Jiuhua massif overlaps with the mean paleomagnetic pole of SCB indicating that the hypothesis of important strike-slip motion of the Lower Yangtze area with respect to SCB could be ruled out. According to these results, a permissive emplacement mechanism with vertical magma injection, coeval with a weak regional deformation, was inferred. However, the shape of the granitic massif, details of the emplacement mechanism, as well as the regional tectonic setting of the magmatic emplacement remained unknown.

As unveiled by several previous studies, the determination of pluton shape and the understanding of emplacement mechanism can give insights on the regional tectonic framework (e.g. Pitcher, 1979, Talbot et al., 2005a and Turrillot et al., 2011). Moreover, it should be pointed out that the emplacement depth can also impact on the shape of the pluton (Pitcher, 1979). Therefore the emplacement depth must be considered when interpreting the regional tectonic bearings of a pluton.

Accordingly, we have performed an $\mathrm{Al}^{\text {total }}$ in amphibole geobarometry and a gravity modeling in the Qingyang-Jiuhua massif. This study aims to answer several unsolved questions, including: (1) What is the shape of the granitic massif? (2) Does this shape comply with the permissive emplacement mechanism suggested in Part I (Wei et al. 2014)? (3) What was the regional tectonic context coeval with the pluton emplacement? (4) Is there a relationship between the emplacement mechanism and the regional tectonic context?

\section{Geological setting}

\subsection{The geological framework of the Lower Yangtze area}

The Lower Yangtze area, located in the northeastern part of the SCB, is composed from north to south by the Dabie Massif, the Lower Yangtze fold belt and the Jiangnan orogenic belt.

The Dabie massif separates the North China Craton (NCC) from the SCB, which collided in Paleozoic time (e.g. Mattauer et al., 1985 and Faure et al., 1999). During the Triassic, the Dabie domain experienced an intracontinental deformation responsible for high to ultra-high pressure metamorphism (Cong and Wang, 1999). During the Cretaceous, an extensional tectonic event gave rise to a migmatitic dome in the North Dabie massif with a pervasively distributed NW-SE stretching lineation and a top-to-the-NW ductile shearing (Faure et al., 2003, Ji et al., 2011 and Wang et al., 2011). During the exhumation of the North Dabie massif, numerous syn-kinematic plutons were emplaced with ductilely sheared boundaries also indicating a NW-SE extension (Hacker et al., 1998 and Faure et al., 2003). In the last stage, the Dabie massif was bounded by brittle normal faults leading to the formation of Cretaceous half graben basins infilled by red continental sediments (Mercier et al., 2007 and Lin et al., 2009).

The Lower Yangtze fold belt, which was intruded during the Early Cretaceous by the Qingyang-Jiuhua massif, consists of a Neoproterozoic to Early Triassic marine sedimentary series. This series was deformed by a south-directed fold and thrust belt in response to the intra-continental subduction of the Dabie massif (Schmid et al., 1999). It is also proposed that to the south of this belt, some folds and thrusts may relate to the reactivation of the

Neoproterozoic Jiangnan orogenic belt during the Triassic to Jurassic times (Li et al., 2010b). Except numerous graben and half-graben basins opened inside the Lower Yangtze fold belt 
(AHBGMR, 1987), the structure and evolution of the Cretaceous extensional event are still poorly constrained.

The Jiangnan orogenic belt is a Neoproterozoic orogen characterized by ophiolitic suture and high-pressure metamorphism, which led to the formation of the SCB (Charvet et al., 1996, Shu et al., 2006 and Li et al., 2009b). In the Triassic, north-directed fold and thrust were formed (Chu and Lin, 2014) and a series of antiforms were developed there in response to the deep continental subduction of the Dabie Massif, in order to accommodate the on-going convergence between NCC and SCB (Faure et al., 1996, Faure et al., 1998, Lin et al., 2000 and Lin et al., 2001). During the Cretaceous, the Jiangnan orogenic belt was characterized by extensional structures, such as the Wan-Zhe-Gan NE-SW striking normal fault system and intracontinental half-graben basins (Gilder et al., 1991, Goodell et al., 1991 and Yu et al., 2007).

\subsection{The Qingyang-Jiuhua massif}

The Qingyang-Jiuhua massif, located in the Lower Yangtze fold belt, mainly consists of the granodioritic Qingyang and the monzogranitic Jiuhua plutons. They are mainly composed of granodiorite with a diorite rim around the northeastern boundary and monzogranite together with some alkali feldspar granite. Geological investigations indicate that along its boundary, the Jiuhua pluton captured several blocks from the Qingyang pluton. The entire massif is intruded by NE-SW or N-S striking microgranite dykes (Fig. 2; AHBGMR, 1987). 


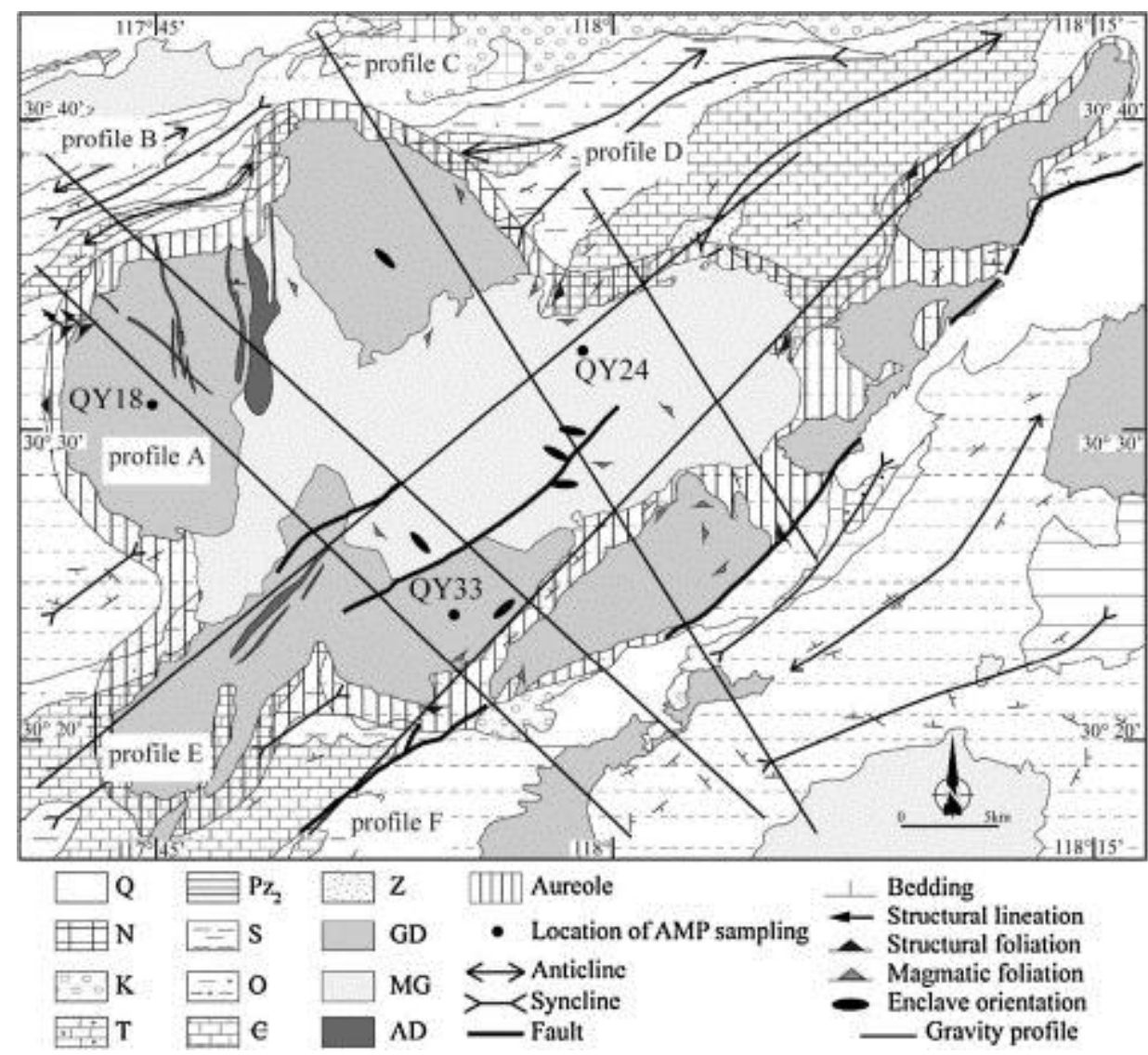

Fig. 2. : Simplified geological map of the Qingyang-Jiuhua massif and its surrounding area with gravity modeling profiles (Fig. 7). Q: Quaternary, N: Tertiary, K: Cretaceous, T: Triassic, $\mathrm{Pz}_{2}$ : Upper Paleozoic, S: Silurian, O: Ordovician, $\in$ : Cambrian, Z: Sinian, GD: Granodiorite, MG: Monzogranite, AD: Acidic dyke.

In the Qingyang pluton, amphibole and biotite yield similar ${ }^{40} \mathrm{Ar}-{ }^{39} \mathrm{Ar}$ ages at $137.1 \pm 1.4 \mathrm{Ma}$, and in the Jiuhua pluton, biotite yields $122.7 \pm 1.2 \mathrm{Ma}$ (Chen et al., 1985). These ages suggest a fast cooling of the massif. Recently, several zircon $\mathrm{U}-\mathrm{Pb}$ geochronological studies were performed on the Qingyang-Jiuhua massif in order to acquire precise emplacement ages. The Qingyang granodiorite is variously dated at $144.8 \pm 0.7 \mathrm{Ma}$ (Chen et al., 2005), $140 \pm 1.1 \mathrm{Ma}$ (Xu et al., 2010) and 139.4 $\pm 1.8-142.0 \pm 1.0 \mathrm{Ma}$ (Wu et al., 2012). The Jiuhua monzogranite yields zircon $\mathrm{U}-\mathrm{Pb}$ ages at $133.2 \pm 1.3 \mathrm{Ma}$ (Xu et al., 2010), and $130.3 \pm 1.8-131.0 \pm 2.6 \mathrm{Ma}$ (Wu et al., 2012). The alkali feldspar granite of the Jiuhua pluton is dated by zircon and monazite U-Pb methods at $129 \mathrm{Ma}$ and $127 \mathrm{Ma}$, respectively (Xu et al., 2010).

\section{Geobarometry using the total Al-content of magmatic amphibole}

The emplacement mechanism of a pluton is strongly affected by the viscosity contrast between melts and their surrounding country rocks (Pitcher, 1979). If the viscosity contrast is low, the diapirism is the main mechanism (e.g. Charles et al., 2009). If the viscosity of country rocks is much higher than that of the melts, injection may become a likely mechanism (e.g. Talbot et al., 2005a). It is shown that the rheology of crustal rocks depends on depth 
(Sibson, 1983). Therefore it is useful to estimate the emplacement depth by calculating the pressure with the help of appropriate magmatic paragenesis.

Furthermore, the knowledge of emplacement depth is an important factor, as it can influence the deformation style of the country rocks around a pluton. The pluton-related deformation is mostly brittle vs. ductile in the upper and lower crust, respectively. Since the shape of a pluton is affected by pre-existing structures and lithological discontinuities (Pitcher, 1979;

Aranguren et al., 2003), the depth estimation becomes essential for providing constraints on the interpretation of a gravity model.

Since the Qingyang and Jinhua plutonic rocks contain green calcic amphiboles, it is possible to use the total aluminum content of amphibole rims as a barometer to estimate the intrusion depth, by assuming that the magmatic amphibole equilibration continues until wet solidus conditions are reached, and that it ceases in the subsolidus domain because the fluid escapes rapidly after solidification of the pluton (Hammarstrom and Zen, 1986, Hollister et al., 1987 and Schmidt, 1992). However, the Al-in amphibole barometer is sensitive to oxygen fugacity and to temperature (Anderson and Smith, 1995). Therefore, if the amphibole-bearing granitoids are emplaced at conditions inconsistent with experimental calibrations, pressures derived using these calibrations may differ by a factor of two or more from the real pressures. Since magnetite is present in the magmatic paragenesis of the Qingyang and Jinhua plutons, the oxygen fugacity during the crystallization can be considered high enough to prevent a misuse of the barometer.

\subsection{Methodology}

Element analyses of minerals were performed using a fully automated CAMECA CAMEBAX electron microprobe, jointly managed by BRGM, CNRS and the University of Orléans. The accelerating voltage was $15 \mathrm{kV}$, and the beam current was $10 \mathrm{nA}$. The beam size was set to $10 \mu \mathrm{m}$. Counting time was $10 \mathrm{~s}$ on peak and $10 \mathrm{~s}$ on background for all elements. Natural and synthetic silicates and oxides were used as standard. The collected data were corrected with the ZAF procedure using PAP software provided by CAMECA.

Three samples (QY18, QY24, QY33 with locations shown in Fig. 2) were chosen to estimate the emplacement depth using amphibole compositions. The mineral assemblage in both granodiorite (QY18 and QY33) and monzogranite (QY24) consists of green calcic amphibole, biotite, plagioclase, alkali feldspar, titanite, magnetite and quartz (Fig. 3). The granodiorite shows a granular texture (Fig. 3a-d), whereas the monzogranite is porphyritic with phenocrysts of biotite, plagioclase, alkali feldspar, titanite, magnetite, quartz, and rare amphibole surrounded by a fine-grained groundmass of quartz and feldspar (Fig. 3e, f, h and i). In both types of rocks, plagioclase shows an optical zonation, and alkali feldspar is perthitic (Fig. 3c and e). Amphibole and titanite grains display magnetite exsolutions (Fig. 3b, c, e and f). In granular granodiorite, quartz infills the space between other euhedral to subeuhedral minerals (Fig. 3a and b). 

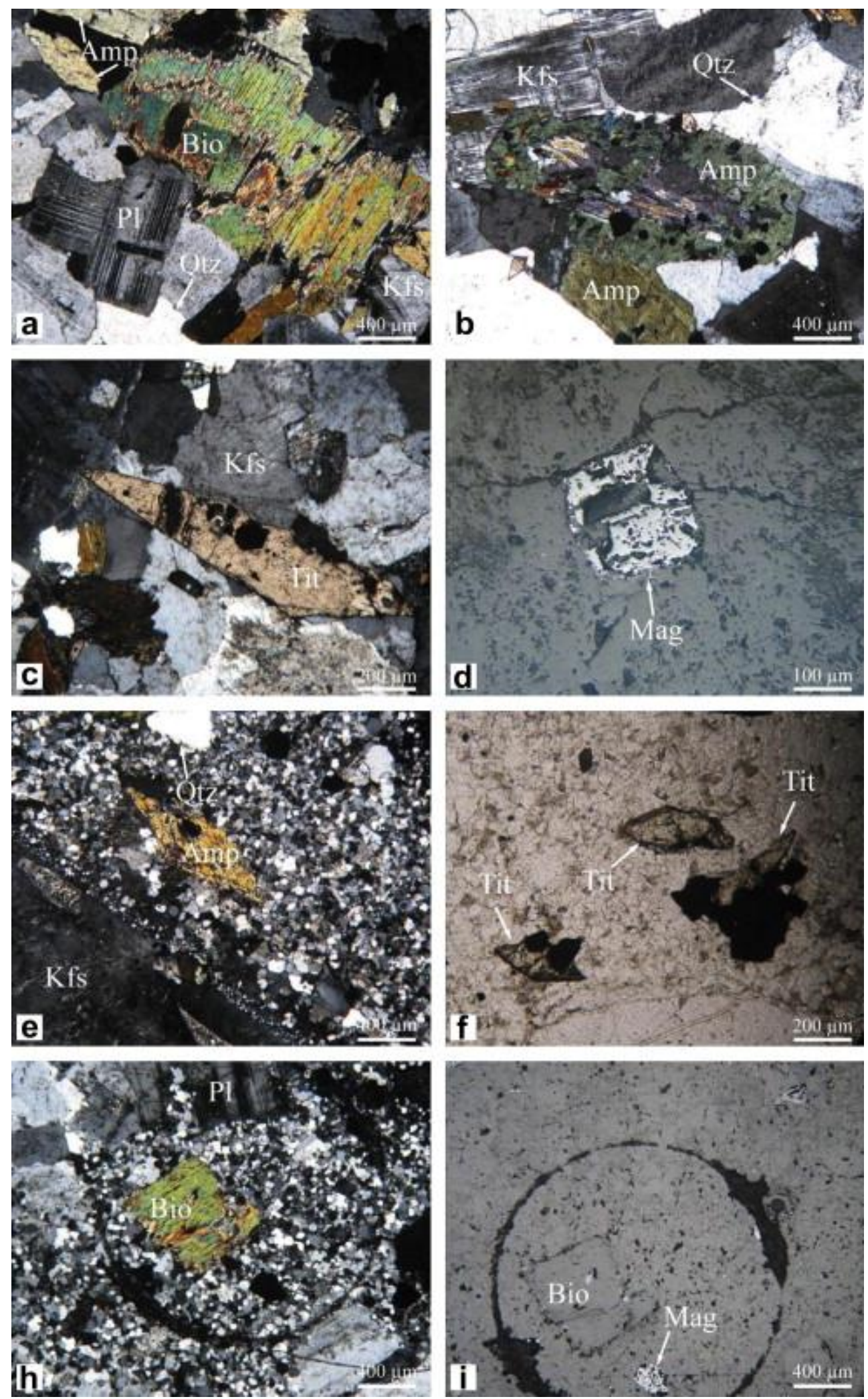

Fig. 3. : The mineral assemblage of the Qingyang-Jiuhua massif. Amp: amphibole, Bio: biotite, Pl: plagioclase, Kfs: alkaline feldspar Qtz: quartz, Tit: titanite and Mag: magnetite. a, $\mathrm{b}, \mathrm{c}$ and $\mathrm{d}$ are from the granodiorite of the Qingyang pluton. e, $\mathrm{f}, \mathrm{h}$ and $\mathrm{i}$ are from the monzogranite of the Jiuhua pluton. 
We analyzed both cores and rims of plagioclase and amphibole grains in order to recognize possible heterogeneities. Attention was also paid to keep away from the magnetite exsolution in amphibole, which can change the total Al content of amphibole in the adjacent area

(Hammarstrom and Zen, 1986).

\subsection{Results}

The typical compositions of plagioclase and amphibole rims are shown in Table 1. Amphibole formula are calculated according to the procedure recommended by the International Mineralogical Association (Leake et al., 1997), with the assumption that there is no $\mathrm{Fe}^{3+}$ in the amphibole lattice. The results show that most of the amphibole rims have compositions of a magnesiohornblende, while a few rim compositions correspond to edenite (Fig. 4).

Table 1.

Representative chemical compositions of amphibole and plagioclase.

Sample QY33-1 QY18-3 QY24-2 QY33-1 QY18-2 QY24-5

Mineral Amp Amp Amp Pl Pl Pl

$\begin{array}{lllllll}\mathrm{SiO}_{2} & 47.355 & 49.715 & 48.241 & 58.942 & 58.893 & 61.190 \\ \mathrm{TiO}_{2} & 1.161 & 0.646 & 0.729 & 0.048 & 0.025 & 0.000 \\ \mathrm{Al}_{2} \mathrm{O}_{3} & 6.912 & 5.011 & 5.615 & 25.109 & 24.927 & 24.156 \\ \mathrm{FeO} \text { tot } & 14.066 & 12.797 & 14.551 & 0.068 & 0.166 & 0.032 \\ \mathrm{MgO} & 13.404 & 15.127 & 13.391 & 0.012 & 0.074 & 0.000 \\ \mathrm{MnO} & 0.613 & 0.842 & 1.444 & 0.000 & 0.010 & 0.000 \\ \mathrm{CaO} & 11.620 & 11.585 & 11.654 & 7.197 & 7.095 & 5.345 \\ \mathrm{Na}_{2} \mathrm{O} & 1.157 & 0.913 & 1.019 & 7.531 & 7.415 & 8.399 \\ \mathrm{~K}_{2} \mathrm{O} & 0.734 & 0.348 & 0.532 & 0.105 & 0.199 & 0.222 \\ \text { Total } & 97.022 & 96.984 & 97.176 & 99.012 & 98.804 & 99.344\end{array}$

$\begin{array}{lllllll}\mathrm{Si}^{4+} & 7.03 & 7.30 & 7.17 & 2.66 & 2.66 & 2.73 \\ \mathrm{Ti}^{4+} & 0.13 & 0.07 & 0.08 & 0.00 & 0.00 & 0.00 \\ \mathrm{Al}^{3+\text { tot }} & 1.21 & 0.87 & 0.98 & 1.33 & 1.33 & 1.27 \\ \mathrm{Fe}^{2+} & 1.75 & 1.57 & 1.81 & 0.00 & 0.01 & 0.00 \\ \mathrm{Mg}^{2+} & 2.97 & 3.31 & 2.97 & 0.00 & 0.00 & 0.00 \\ \mathrm{Mn}^{2+} & 0.08 & 0.11 & 0.18 & 0.00 & 0.00 & 0.00 \\ \mathrm{Ca}^{2+} & 1.85 & 1.82 & 1.86 & 0.35 & 0.34 & 0.26 \\ \mathrm{Na}^{+} & 0.33 & 0.26 & 0.29 & 0.66 & 0.65 & 0.73 \\ \mathrm{~K}^{+} & 0.14 & 0.07 & 0.10 & 0.01 & 0.01 & 0.01 \\ \text { Total } & 15.47 & 15.38 & 15.44 & 5.01 & 5.00 & 5.00\end{array}$

An $(\% \mathrm{~mol}) \quad-\quad \begin{array}{lllllll} & - & & - & 35 & 34 & 26\end{array}$

$\mathrm{Mg} /(\mathrm{Mg}+\mathrm{Fe}) 0.63 \quad 0.68 \quad 0.62 \quad-\quad \begin{array}{lllll} & 0 & 0 & - & -\end{array}$

Amp: amphibole, Pl: plagioclase, cations' values are calculated on the basis of $23 \mathrm{O}$ and $2 \mathrm{OH}$ for amphibole. 

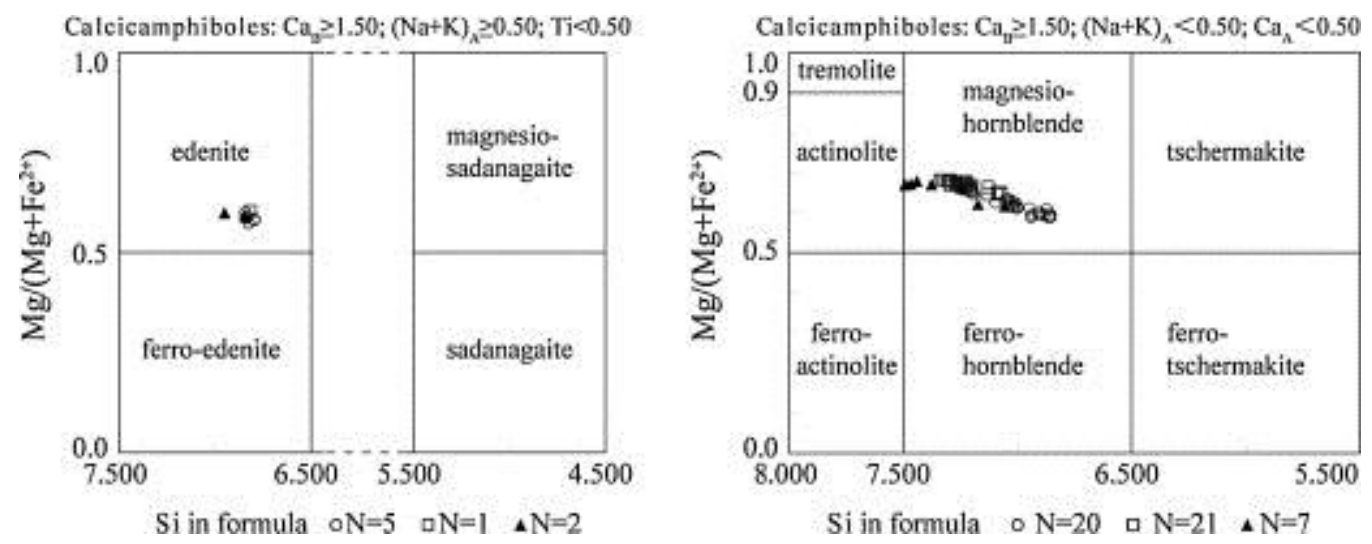

Fig. 4. : Chemical composition of calcic amphiboles analyzed in three samples coming from the Qingyang-Jiuhua massif and location of samples shown in Fig. 2: QY18 (open square), QY24 (solid triangle) and QY33 (open circle). The formula is calculated on the basis of $23 \mathrm{O}$ with $2 \mathrm{OH}$.

The amphibole cores are richer in aluminum than the rims. This zonation cannot be used to reconstruct the pressure evolution during the crystallization of the rock. In fact, according to the phase rule, the total $\mathrm{Al}$ content of amphibole may be considered as a barometer only if the amphibole is crystallized in equilibrium with nine phases at temperatures close to the solidus (Schmidt, 1992), which is not the case as the amphibole begins to form. Therefore only the rim compositions were considered to be able to estimate the equilibrium pressures at the solidus (Hollister et al., 1987), the equilibrium hypothesis being in accordance with a rather constant anorthite content of plagioclase rims between 25 and $35 \mathrm{~mol} \%$ (Table 1).

The composition of amphibole rims shown in the plot of $\mathrm{Al}^{\text {tot }}$ pfu (per formula unit) $\mathrm{vs}^{\mathrm{AV}}$ pfu (Fig. 5) fits well with the linear regression on the data obtained for low-pressure rocks studied by Hammarstrom and Hollister (1986). This result can be clearly stated by using the Al-in amphibole geobarometer calibrated by Schmidt (1992). Equilibrium of the assemblage composed of amphibole, biotite, plagioclase, orthoclase, quartz, titanite, Fe-Ti-oxide, melt and vapor from a natural tonalite, $15-20^{\circ} \mathrm{C}$ above its wet solidus, was fit by the equation:

$\mathrm{P}( \pm 0.6 \mathrm{kbar})=-3.01+4.76$ Altot,

where $\mathrm{Al}^{\text {tot }}$ is the total $\mathrm{Al}$ content of amphibole in cations pfu (calculated to $23 \mathrm{O}$ and $2 \mathrm{OH}$ ). For QY33, the total Al content of amphibole is between 1.03 and 1.46 cations pfu, which gives, after Schmidt (1992), a pressure between 1.9 and $3.9 \mathrm{kbar}$. For QY24, the $\mathrm{Al}^{\text {total }}$ values are in the range between 0.63 and 1.39 cations pfu, and the pressure is therefore lower than 3.6 kbar. For QY18, the $\mathrm{Al}^{\text {total }}$ value varies from 0.83 to 1.40 , which leads to a pressure lower than 3.7 kbar. 


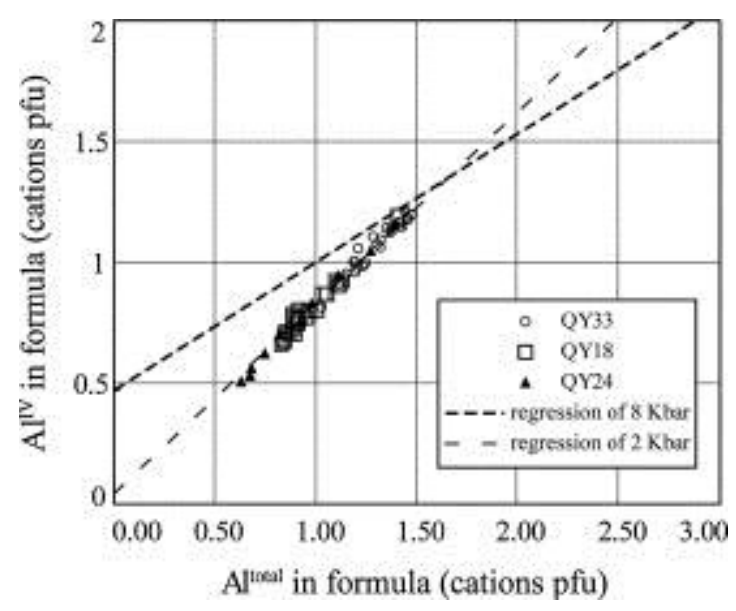

Fig. 5. : $\mathrm{Al}^{\mathrm{IV}}$ and $\mathrm{Al}^{\text {total }}$ bivariate diagram of the Qingyang-Jiuhua massif. $\mathrm{Al}^{\mathrm{IV}}$ and $\mathrm{Al}^{\text {total }}$ values are calculated on the basis of $23 \mathrm{O}$ and $2 \mathrm{OH}$ (see Fig. 2 for location of samples). All values are from the rims of the amphibole grains. The regression lines are reported after Hammarstrom and Zen (1986).

As a result, all pressure values obtained using the total aluminum content of amphibole rims are clearly lower than $4 \mathrm{kbar}$. And the average pressure of QY33, QY24 and QY18 are $3.2 \pm 0.6 \mathrm{kbar}, 1.4 \pm 1.3 \mathrm{kbar}$ and $1.6 \pm 0.6 \mathrm{kbar}$, respectively. If the assumption that no equilibration between amphibole and other phases took place in the subsolidus conditions is correct, this low pressure indicates that the emplacement of the Qingyang and the Jiuhua plutons occurred at a shallow depth of 5-12 km. This estimate is in accordance with the presence of andalusite in hornfels in the metamorphic aureole of the massif.

\section{Gravity method}

Since gravity modeling has long been successfully used to address the geometry of plutons at depth (e.g. Aranguren et al., 2003, Talbot et al., 2005a, Joly et al., 2009 and Turrillot et al., 2011), we applied this method to constrain the shape of the Qinyang-Jiuhua massif. The Bouguer anomaly map is acquired from the Chinese 1:200000 Bouguer anomaly database. We modeled four NW-SE profiles and two NE-SW ones, covering the entire massif and crosscutting with each other (Fig. 6). 


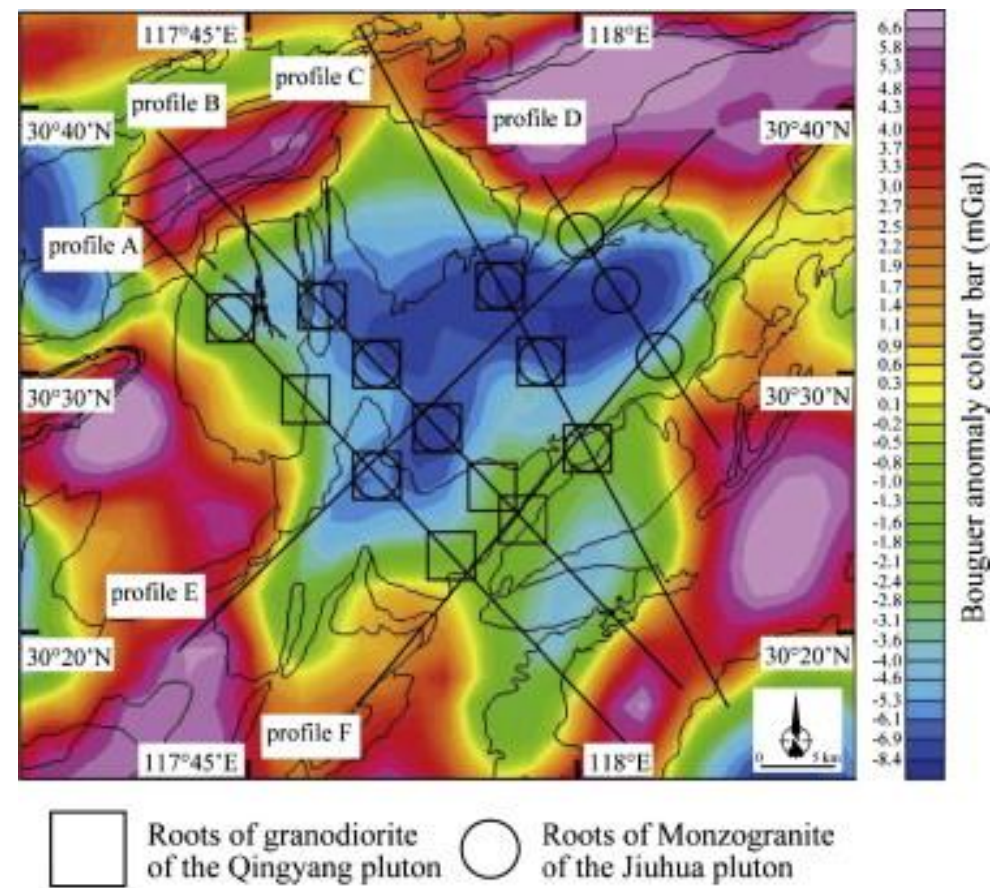

Gravity model profile

Fig. 6. : Residual Bouguer anomaly map of the Qingyang-Jiuhua massif and its surrounding area with modeled gravity profiles (shown in Fig. 7).

\subsection{Bouguer regional and residual anomaly}

The Bouguer map around the Qinyang-Jiuhua massif displays a clear long wavelength regional component, which blurs the local signature of the massif. Since our study focuses on anomalies related to density contrasts caused by lithologies in the first kilometers of the crust, we firstly removed the effect of deep density contrasts from the Bouguer map. This can be achieved by several techniques, which are aimed at removing the long wavelengths from the Bouguer anomaly. After several attempts, we used a low-pass Butterworth filter with a cutoff wavelength of $70 \mathrm{~km}$, which provided a regional anomaly map approximating well the original Bouguer map. Then we subtracted this regional anomaly from the original Bouguer anomaly to obtain a residual (or local) Bouguer map (Fig. 6).

In the original Bouguer anomaly map, one can observe that there is a clear regional trend from NW to SE, and that the anomaly contours cross-cut the pluton boundaries. In the residual Bouguer anomaly map, the negative and positive anomalies fit well with the granite and country rocks, respectively (Fig. 6). The contours of the residual Bouguer anomaly map are parallel to the boundary of plutons (Fig. 6). Within the country rocks, the NE-SW elongated pattern is related to the fold trend. The highest intensity anomalies correspond to the Cambrian and Ordovician formations, which have the highest density in the studied area (Table 2). Based on the above observations, we consider that the residual Bouguer anomaly map properly accounts for the structures of the upper crust and can be used to model the geometry of the plutons and country rocks. 
Table 2. : Rock densities used in gravity modeling.

\begin{tabular}{|c|c|c|c|c|}
\hline Rocks & $\begin{array}{c}\text { Average of } \\
\text { measured density } \\
\left(\mathrm{g} / \mathrm{cm}^{3}\right)\end{array}$ & $\begin{array}{c}\text { Number of } \\
\text { measured } \\
\text { samples }\end{array}$ & $\begin{array}{c}\text { Standard } \\
\text { derivation } \\
\left(\mathrm{g} / \mathrm{cm}^{\mathbf{3}}\right)\end{array}$ & $\begin{array}{c}\text { Density used in } \\
\text { modeling } \\
\left(\mathrm{g} / \mathrm{cm}^{3}\right)\end{array}$ \\
\hline Granodiorite & 2.7116 & 2 & 0.0013 & 2.712 \\
\hline Monzogranite & 2.6157 & 7 & 0.0168 & 2.616 \\
\hline Alkali granite & 2.6043 & 1 & - & 2.616 \\
\hline Triassic & 2.6983 & 1 & - & 2.698 \\
\hline Devonian & 2.7225 & 1 & - & 2.722 \\
\hline Silurian & 2.7324 & 4 & 0.0568 & 2.732 \\
\hline Ordovician & 2.8435 & 2 & 0.0028 & 2.838 \\
\hline Cambrian & 2.8283 & 1 & - & 2.838 \\
\hline Sinian & 2.6668 & 1 & - & 2.667 \\
\hline
\end{tabular}

Because of the small volume of samples for alkali granite and acidic dykes and the similarity of their density with mozogranite, we use density of monzogranite for these three lithologies in gravity modeling. For the thin Carboniferous and Permian strata, we did not measure the density, but use that of Devonian strata. As the densities of the Ordovician and the Cambrian strata are similar, we use the average density of them in the gravity modeling.

More specifically, the residual Bouguer anomaly features the main geological patterns. To the north, the boundary between the granitic massif and country rocks coincides with a strong anomaly gradient, which suggests a sharp contact between these two geological bodies. To the northeast and to the east, the negative anomaly exceeds the geological boundary, indicating an extension of the massif beneath the country rocks. To the southwest, a positive anomaly on the massif border suggests thinning of the pluton. The lowest negative anomaly is in the center of the massif with a slight NE-SW trend, coincident with the outcrop of the monzogranite, which has the lowest density. Around the monzogranite, the contours of the lowest negative anomalies are convex along the granodioritic border, suggesting that the monzogranite might continue beneath the granodiorite.

In order to quantify these observations in shape and depth, we have performed forward gravity modeling along 6 sections cross-cutting the massif.

\subsection{Gravity modeling}

The boundaries of geological bodies, as well as the structure of country rocks of our model, are derived from the 1:200000 Chinese geological map. The thickness of the sedimentary layers is derived from the geological map notebook. The densities of the main lithologies encountered in the study area were measured with the double weighting method (Table 2). In order to take into account the effect of geological bodies around our target massif, our profiles extend for several tens of kilometers in the country rocks around the granites to avoid edge effects.

We constructed four profiles in the NW-SE direction (Profiles A to D in Fig. 7), which are perpendicular to the elongation of the negative anomaly zone inside the massif, as well as to the elongation of fold belts in the country rocks. In this direction, variations of thickness of the massif and the shapes of country rock folds can be well constrained. Also, we constructed two profiles (Profiles E and F in Fig. 7) in the NE-SW direction (Fig. 6), perpendicular to Profiles A to D. These two crossing profiles are expected to better recognize the geometries of geological bodies at depth, and ascertain the models where they cross. 

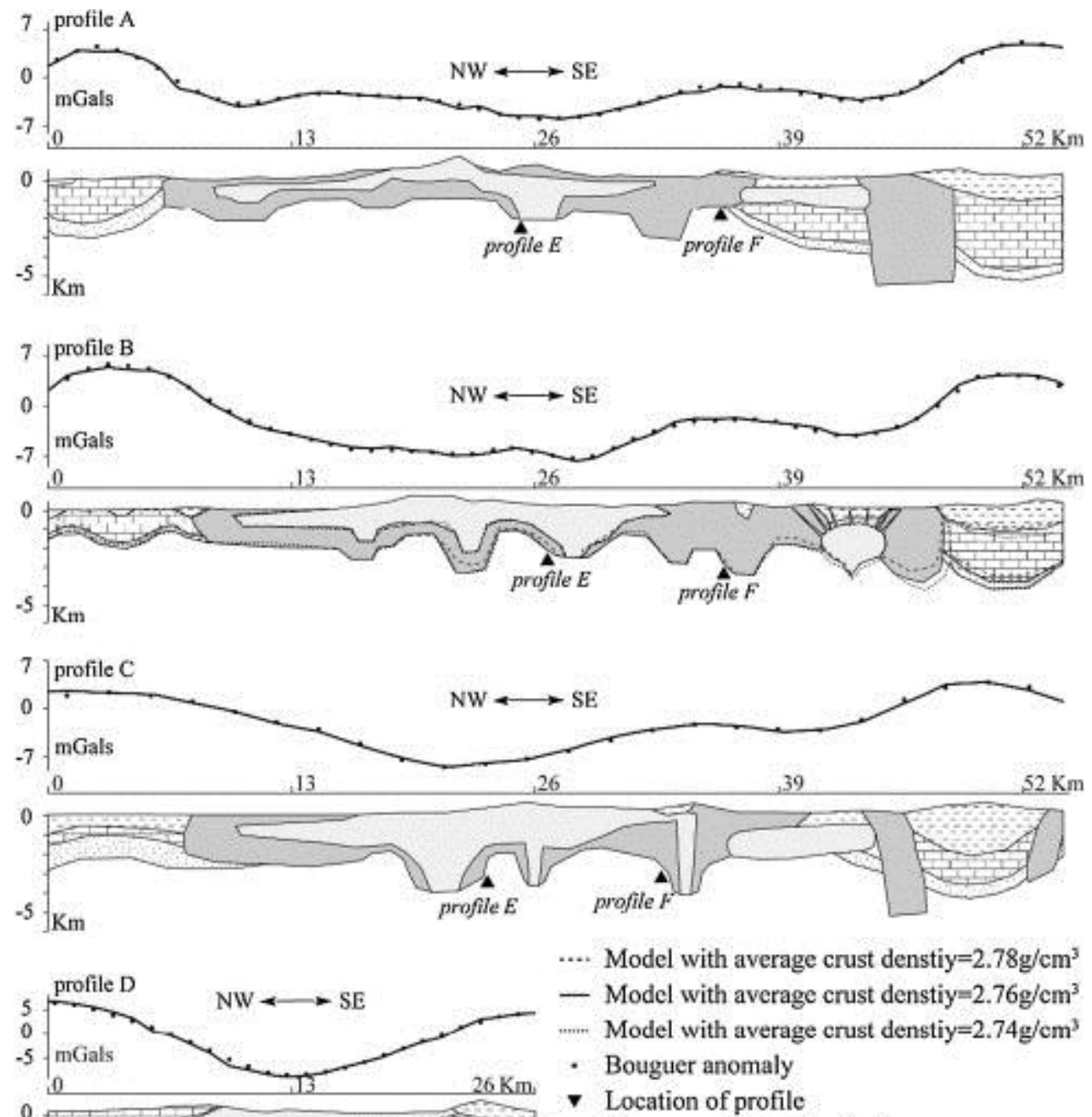

... Model with average crust denstiy $=2.78 \mathrm{~g} / \mathrm{cm}^{3}$

- Model with average crust denstiy $=2.76 \mathrm{~g} / \mathrm{cm}^{3}$

...... Model with average crust denstiy $=2.74 \mathrm{~g} / \mathrm{cm}^{3}$

- Bouguer anomaly

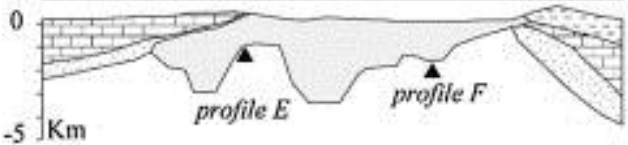

- Location of profile

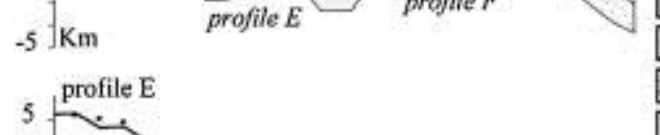

Monzogranite $\left(2.62 \mathrm{~g} / \mathrm{cm}^{3}\right)$

Granodiorite $\left(2.71 \mathrm{~g} / \mathrm{cm}^{3}\right)$

Silurian $\left(2.73 \mathrm{~g} / \mathrm{cm}^{3}\right)$
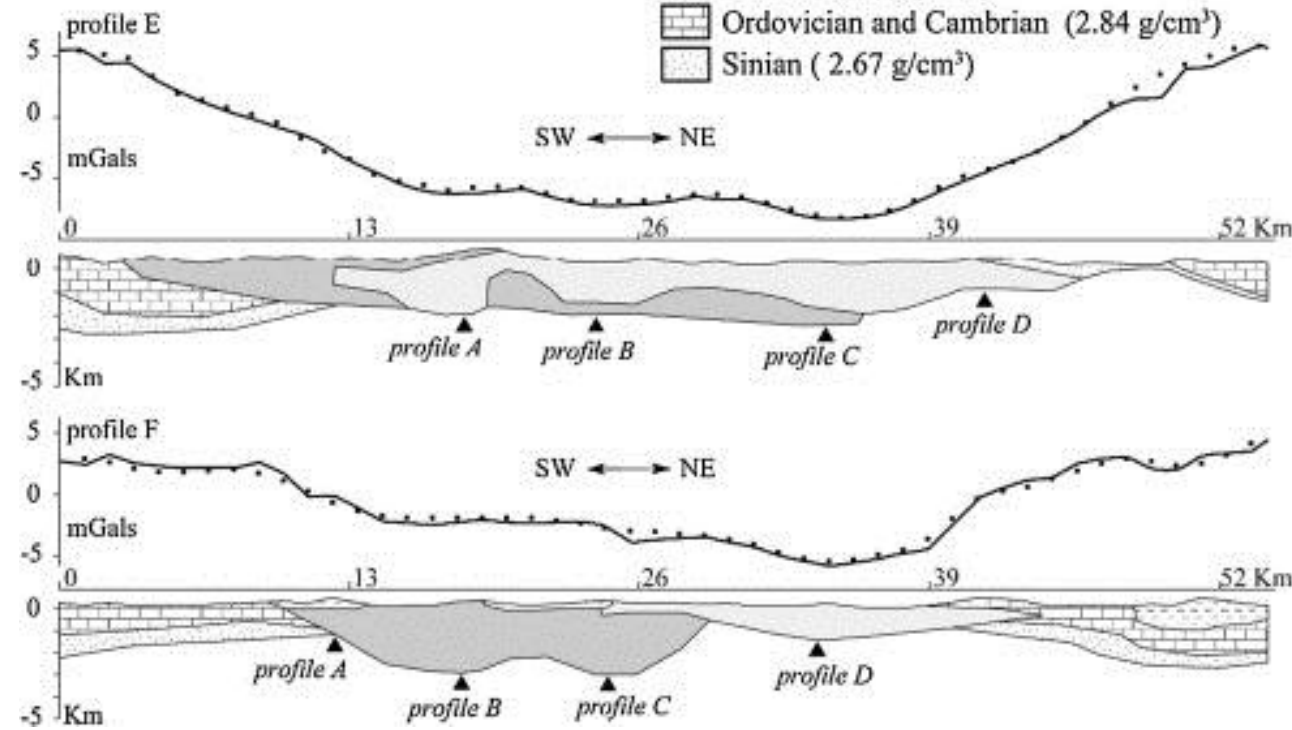

Fig. 7. : Forward gravity modeling conducted along 6 profiles across the Qingyang-Jiuhua massif (see Fig. 2 and Fig. 6 for profiles' locations). 
One outstanding characteristic of our model is that all the four NE-SW profiles display significant thickness variations of the granitic pluton. Several "sinks" of granite reaching a thickness of about $4 \mathrm{~km}$ are identified in each profile. Between these "sinks", the thickness of the granite is $1-2 \mathrm{~km}$ in average (Fig. 7). When considering all gravity profiles, the overall model of the granite suggests a laccolith-shaped upper part and a lower part formed by several "sinks".

When transferring these "sinks" onto the gravity map (Fig. 6), it can be noticed that they align in the NE-SW direction, along the negative anomalies. Indeed, the overall shape of the massif appears to be controlled by a series of NE-SW elongated "sink zones" parallel to Profiles E and F. In these two profiles, the massif displays little variations of thickness.

Whether not unique, the overall model agrees with available geological and geophysical information. It can be discussed as follows. (1), The residual Bouguer gravity anomaly is well reproduced by the calculated effect of the model; (2), the thickness of the geological bodies is consistent in all profiles; (3), the structure of country rocks provided by the geological map is consistently reproduced by the folded geometries in the model. More specifically, our model displays some variations of thickness within these folds; it is reasonable to assume that the thickness of strata can locally vary as a result of shortening during the Triassic thrusting and folding event (Schmid et al., 1999). Also, because the density used in the modeling is an average value, the slight spatial variations of rock density may be another reason for deviations in strata thickness in our model.

Finally, the density of the undifferentiated upper crust beneath our model $\left(2.76 \mathrm{~g} / \mathrm{cm}^{3}\right)$ is an average value based on the Crust 2.0 model (Bassin et al., 2000). In order to evaluate the impact of errors on this density, we illustrate on Profile B in Fig. 7 the effect on the model geometry when we introduce $\pm 0.02 \mathrm{~g} / \mathrm{cm}^{3}$ density variations. The result shows that in some places, the granitic massif floor would vary about a maximum of $500 \mathrm{~m}$. But these variations do not significantly modify the overall shape of the model.

\section{Discussion}

In order to understand the mechanism and the tectonic context of the Qingyang-Jiuhua massif emplacement, the emplacement depth and the shape of the massif have been established by $\mathrm{Al}^{\mathrm{total}}$ in amphibole geobarometry and 2D gravity modeling. For providing a clear view on the bearings of these methods, in this discussion we will firstly summarize the results, and then interpret them in terms of emplacement mechanism and the regional tectonic setting.

\subsection{Summary of the results}

The microscopic observation of the granodiorite and monzogranite thin sections indicates that the equilibrium has been reached. The An values in the plagioclase rims are within 25$35 \mathrm{~mol} \%$, and the magnesiohornblende and edenite nature of amphibole guarantee the validity of the geobarometric calculation. The estimated pressure does not exceed $4 \mathrm{kbar}$. The average pressure of QY33, QY24 and QY18 are $3.2 \pm 0.6 \mathrm{kbar}, 1.4 \pm 1.3 \mathrm{kbar}$ and $1.6 \pm 0.6 \mathrm{kbar}$, respectively. This result is consistent with the appearance of andalusite in the metamorphic aureole zone. The negative Bouguer residual anomaly fits with the massif boundary (Fig. 6). Modeling of this anomaly along cross-sections reveals significant thickness variations along all the four NW-SE profiles. They display several "sink" shapes in both the granodiorite of the Qingyang pluton and the monzogranite of the Jiuhua pluton, while the two NE-SW gravity profiles display gently undulating interfaces. The "sink" shapes of these two plutons overlap with each other in each individual NW-SE profile. 


\subsection{Implications on the emplacement mechanism of the massif}

The emplacement mechanism of a granitic pluton is defined as permissive or forceful, depending on the deformation produced in the surrounding country rocks (Pitcher, 1979). A permissive emplacement means that a space is created within the crust to allow the magma emplacement, and therefore the country rocks will not record a significant ductile deformation produced by the magma pressure, while the forceful one is just on the contrary. During its emplacement, the magma injection can be vertical or lateral. For the former, one or several feeding roots exist beneath the pluton and the emplacement occurs via vertical conduits (e.g. Turrillot et al., 2011); While for the latter, single or multiple roots occur in one side of the pluton, and magma flows laterally (e.g. Aranguren et al., 2003 and Talbot et al., 2004). The forceful or permissive emplacement mechanism and the vertical or lateral magma intrusion mode will be discussed below for the studied massif.

\subsubsection{Possible emplacement mechanism}

According to our geobarometry result, both the Qingyang and the Jiuhua plutons intrude at a shallow crustal depth between 5 and $12 \mathrm{~km}$. This is consistent with the absence of a regional ductile shear zone along the pluton boundary and the lack of significant ductile deformation in the country rocks (Wei et al., 2014). Since the upper crust is relatively cold, a shallow depth magma intrusion produce a sharp temperature contrast between the pluton and its country rocks, associated with a fast cooling of the pluton. The shallow depth calculated by $\mathrm{Al}^{\text {total }}$ in amphibole geobarometry is consistent with the fast cooling rate shown by amphibole and biotite ${ }^{40} \mathrm{Ar}-{ }^{39} \mathrm{Ar}$ dating (Chen et al., 1985). Usually at this depth, the deformation is dominated by brittle structures, providing fractures used as magma conduits, and creating space to accommodate the magma injection. This interpretation is supported by the general shape of the massif suggested by the gravity modeling, which shows high angle contacts between the two plutons and between the plutons and country rocks (Fig. 7). Plutons emplaced in the brittle domain at shallow depth are usually featured by a box-like shape, with a flat roof and steep contacts (Myers, 1975), having linear and angular edges controlled by preexisting or syn-emplacement fractures (Pitcher, 1979 and reference therein). These characteristics can be observed in the gravity model of the Qingyang-Jiuhua massif (Fig. 7).

The gravity modeling clearly reveals that the shape of the massif can be divided in the vertical "sinks" lower part and a laccolith-like upper part (Fig. 7a-d). These "sinks" zones are interpreted as the root zones of the granitic massif (e.g. Talbot et al., 2005a and Turrillot et al., 2011). Therefore the massif emplaced in the brittle domain along fractures opened as tension gashes which acted as magma conduits during the pluton emplacement (e.g. Turrillot et al., 2011). Also, the laccolith-like upper part can be interpreted as a magma reservoir whose space is provided by brittle fracturing of the upper crust. Moreover the overlap between the roots of the Jiuhua pluton and the roots of the Qingyang pluton indicates that the magma conduits used by the Qingyang pluton were still active during the emplacement of the younger Jiuhua pluton.

This permissive emplacement scheme is consistent with the conclusion reached in Part I (Wei et al., 2014) in which the macrostructural observations indicate that the previous fold structure of the Lower Yangtze fold belt was not modified, and almost no emplacement-related deformation was recorded in the aureole. Moreover, the paleomagnetic study showed that the emplacement of the Jiuhua pluton did not rotate or push away the neighboring Qingyang pluton. Altogether, these observations indicate that the emplacement of both plutons is permissive rather than forceful. 


\subsubsection{Injection trajectory}

As shown in the residual Bouguer anomaly map (Fig. 6), the contours of the Bouguer anomaly are more or less parallel to the boundary of the massif, and the maximum negative Bouguer anomaly is located in the center of the massif rather than close to the border of the massif. This suggests that the model of feeding on one flank before flowing laterally (e.g. Aranguren et al., 2003, Talbot et al., 2004 and Talbot et al., 2005b) does not hold for the Qingyang-Jiuhua massif.

More details of the shape of the massif are shown in the gravity modeling profiles (Fig. 7). In each NW-directed profile, the top of the massif is flat or gently inclined, and on both sides, the walls are vertical or sub vertical. Several vertical roots are uniformly distributed with more or less the same spacing along the NW-directed profile. This means that the upwelling of the magma occurred vertically or sub-vertically throughout the conduits that were regularly distributed beneath the massif.

This argument is also supported by the AMS foliation pattern shown in Part I (Wei et al., 2014). In the center of the massif, the majority of the AMS foliations are weakly inclined, while they are highly inclined and parallel to the massif boundaries (Fig. 11a in Wei et al., 2014). This AMS foliation pattern was assumed to be acquired due to the vertical and sub vertical injection and the stopping of the magma by the country rocks on the roof as well as asides. However, this assumption outlined by the AMS pattern requires very limited erosion of the massif and thus the AMS sites are very near to the massif roof. This condition is supported by the gravity modeling. There exists a NE-directed narrow stripe of country rocks in the southeast part of the Qingyang-Jiuhua massif, which is crossed by the gravity profile $\mathrm{F}$ (Fig. 2). Considering its narrow shape, the lithology and U-Pb zircon age of the around igneous rocks on both sides (Wu et al., 2012), this stripe is interpreted as a septum in Part I (Wei et al., 2014). Our gravity modeling indicates that the thickness of this country rock stripe is just of a few $100 \mathrm{~m}$, and there exists a thick granodioritic "sink" that connects the outcroping granodiorite on both sides of the country rock stripe. Gravity modeling supports the view that this NE-SW striking narrow country rock stripe is just a septum within the same pluton, suggesting that erosion of the massif was very limited. Thus, the AMS sites are very close to the massif roof, which guarantees the validity of the interpretation of the AMS pattern.

\subsubsection{Overview of the emplacement process}

Based on the discussion of the massif emplacement mechanism above, a three stage emplacement model is proposed. During the first stage, around $142 \mathrm{Ma}$ (Wu et al., 2012), the lower crust was partially melted, and a granodioritic magma was generated. At shallow depth, the crust of the Lower Yangtze fold belt was faulted by regional extension to create tension gashes. Granodioritic magma was injected along several conduits of the tension gashes, before being crystallized, to form the Qingyang pluton. During this process, the rising magma did not exert any obvious pressure on the country rocks.

In the second stage, at about $130 \mathrm{Ma}$ (Wu et al., 2012), due to the continued regional extension, the formerly used magma conduits were reopened, and possibly new ones were formed in the upper brittle crust. At this time, monzogranitic magmas were injected into the opening room and crystallized to form the Jiuhua pluton.

During the third stage, several parallel dykes of microgranite intruded the massif. 


\subsection{Pluton emplacement and regional tectonics}

The pluton roots modeled along the individual gravity profiles can be correlated between the profiles, and thus reveal four nearly parallel NE-SW striking feeder zones (Fig. 7 and Fig. 8). Moreover, the overlapping between the root zones related to the Qingyang and the Jiuhua plutons suggests that the two plutons emplaced in a similar tectonic context; in this area, NWSE maximum stretching tectonics lasted more than $10 \mathrm{My}$.

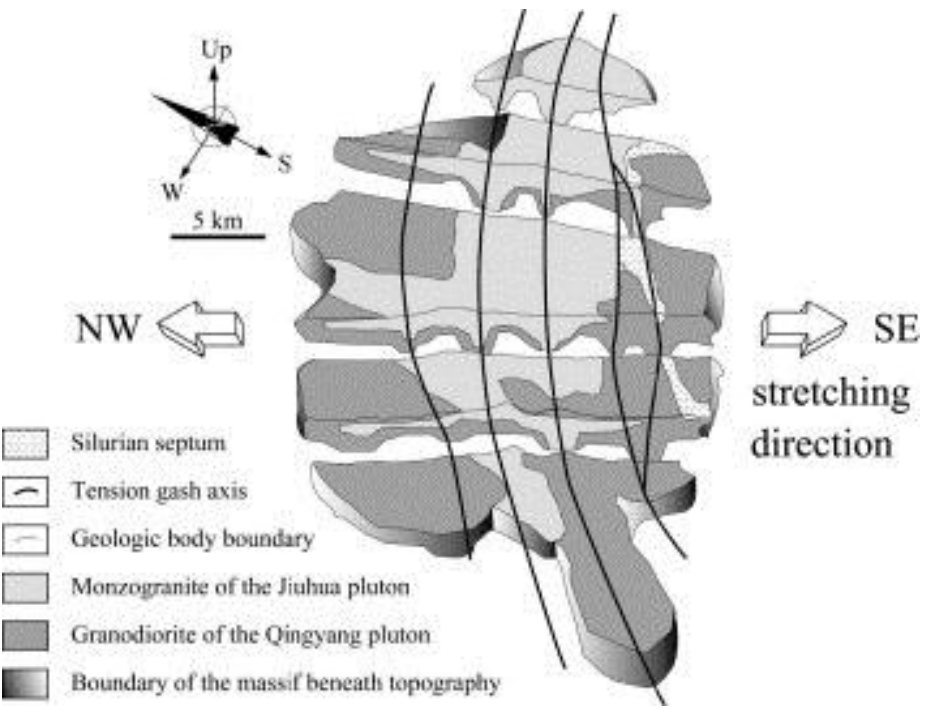

To the south of the Qingyang-Jiuhua massif, in the Jiangnan orogenic belt (Fig. 1), a Cretaceous NE-SW striking normal fault system developed; it is coeval with the emplacement of the Qingyang-Jiuhua massif (Yu et al., 2007). It is reasonable to interpret the NE-SW root zones of the Qingyang-Jiuhua massif as a result of the same tectonic context. 


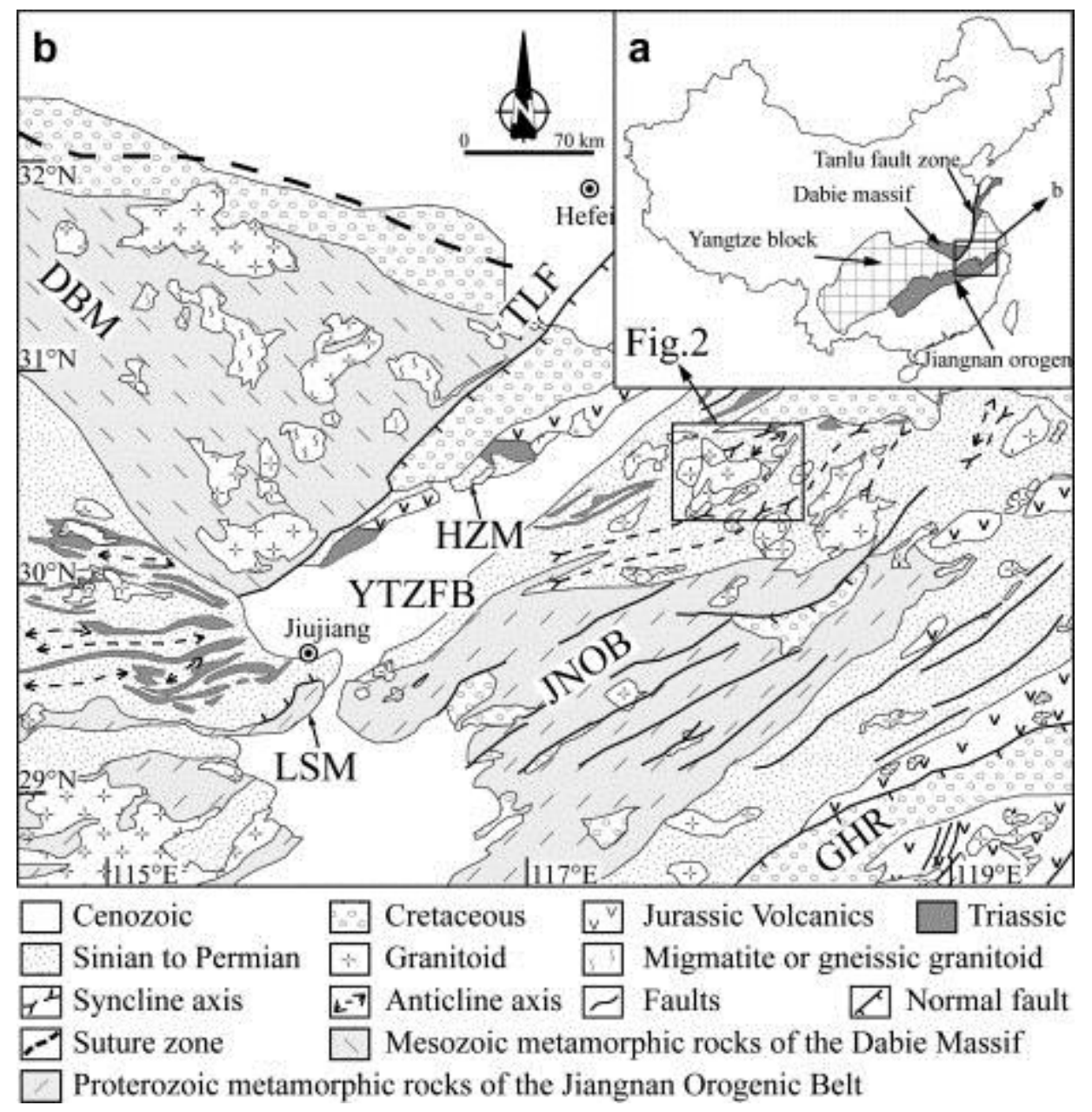

Fig. 1. : Regional geological map of the Lower Yangtze area. TLF: the Tanlu Fault, YTZFB: the Lower Yangtze fold belt, JNOB: the Jiangnan orogenic belt, GHR: the Ganhang rift basin, DBM: the Dabie massif, LSM: the Lushan massif, HZM: the Hongzhen massif.

Accordingly, the NE-SW tension gashes of the Qingyang and the Jiuhua plutons may indicate that the Lower Yangtze area experienced a NW-SE extensional tectonic regime during the plutons' emplacement. The cartographic shape of the Qingyang-Jiuhua massif may also provide insights of this NW-SE extension. For instance, the monzogranite of the Jiuhua massif is rectangle-shaped with a NEE-SWW long side. Also, the NE-SW granodiorite "tail" in the southwestern part of the Qingyang pluton coincides with the location of a tension gash shown in our gravity modeling (Fig. 8). In this context, it is reasonable to interpret this part of the Qingyang pluton as a tension gash.

Metamorphic core complexes or syn-kinematic plutons are usually bounded by low-angle ductile shear zones (i.e. detachment faults) which accommodate large crustal deformation. Conversely, the amount of extension related to the emplacement of the Qingyang-Jiuhua massif was probably weak, because no significant emplacement-related deformation was observed. Therefore, the quantity of the extension is probably just equal to the width of the tension gashes.

This NW-SE extension is however also recorded in the adjacent areas (Fig. 9). For example, in the Dabie massif, which is located to the northwest of the Qingyang-Jiuhua massif (Fig. 9), a pervasively distributed NW-SE lineation with a top-to-the-NW shearing developed inside the North Dabie domain, the Central Dabie migmatite dome and the South Dabie domain 
(Fig. 9). These NW-SE lineations are interpreted to be formed in an extensional context during or soon after the exhumation of the Central Dabie migmatite dome (Faure et al., 2003). Recently, geochronological work has shown that the Central Dabie migmatite dome was formed in two episodes at ca. $137 \mathrm{Ma}$ and ca. $124 \mathrm{Ma}$ (Wu et al., 2007). The former age is consistent with that of the emplacement of the Qingyang-Jiuhua massif. Along the eastern boundary of the Dabie massif, the Tanlu Fault (Fig. 9) also acted as a normal fault with a NW-SE stretching direction at ca. 135-130 Ma (Mercier et al., 2007). The Lushan massif, which is located to the southwest of the Qingyang-Jiuhua massif (Fig. 9), recorded four stages of deformation (Lin et al., 2000). Stage D1, developed a NW-SE lineation with top-tothe-NW motion, is interpreted as a normal detachment ductile shear zone (Lin et al., 2000) and it is dated at about $140 \mathrm{Ma}$ by ${ }^{40} \mathrm{Ar}-{ }^{39} \mathrm{Ar}$ dating on muscovite (Zhu et al., 2010c), coeval with the emplacement of the Qingyang-Jiuhua massif as well. A NW-SE regional extensional tectonic regime seems therefore to characterize this part of the SCB during the Early

Cretaceous.

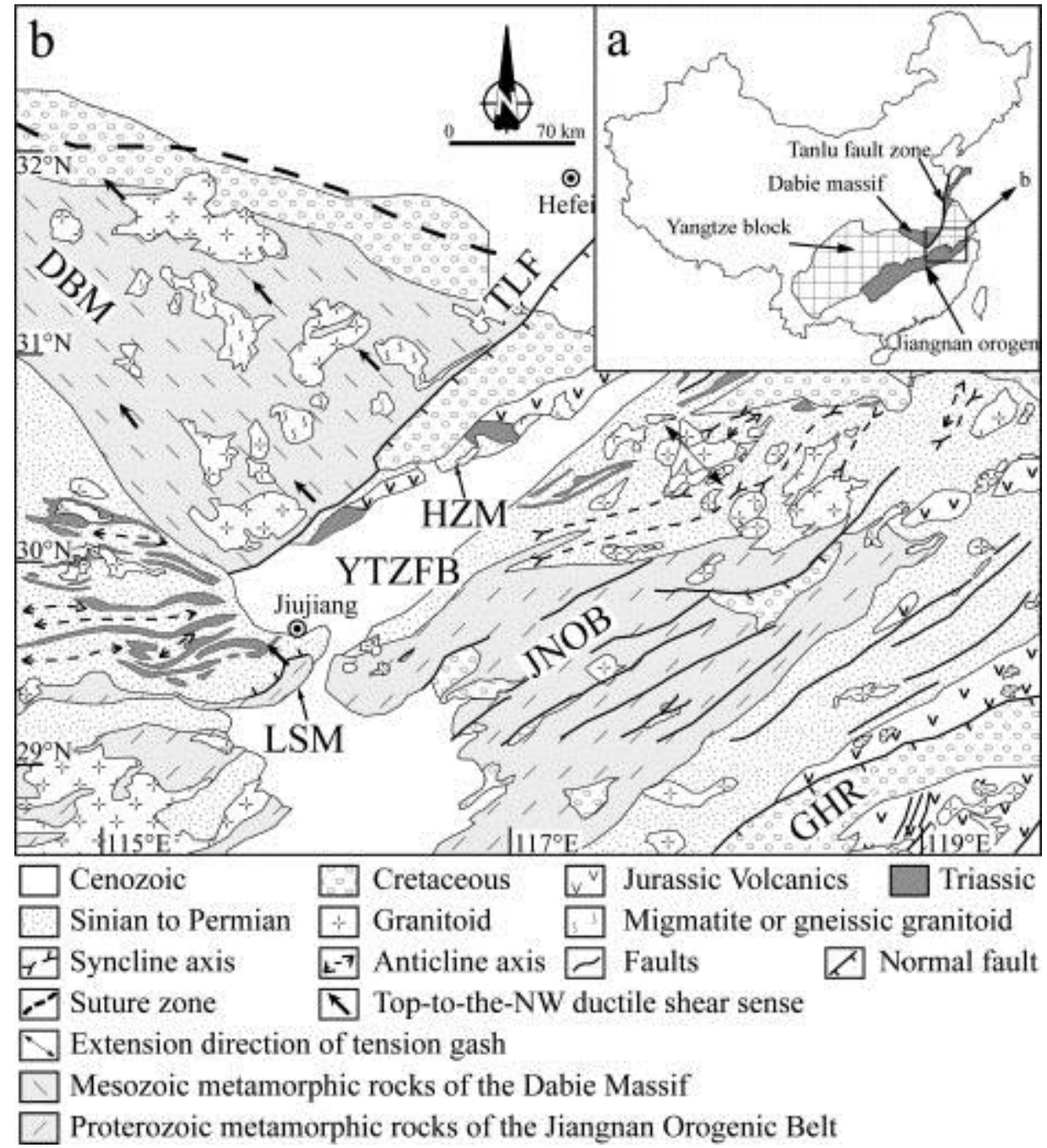

Fig. 9.

Cretaceous tectonic fabrics of adjacent areas of the Qingyang-Jiuhua massif. TLF: the Tanlu Fault, YTZFB: the Lower Yangtze fold belt, JNOB: the Jiangnan orogenic belt, GHR: the Ganhang rift basin, DBM: the Dabie massif, LSM: the Lushan massif, HZM: the Hongzhen mass 


\section{Conclusions}

We can draw the following main conclusions from this study:

(1)

According to the results of the $\mathrm{Al}^{\text {total }}$ in amphibole geobarometry, the box-like shape of the massif and the absence of the regional ductile deformation in country rocks, the Qingyang-Jiuhua massif was emplaced at shallow depth.

(2)

The gravity modeling indicates that the massif consists of a laccolith-shaped upper part and a lower part that contains several vertical "sink" zones. The shape of these "sink" zones can be interpreted as the roots of the massif, which acted as feeder zones. The magma was injected in NE-SW oriented tension gashes which provided magma conduits feeding an upper laccolith-shaped reservoir.

(3)

The Qingyang and Jiuhua granites, which intruded the Lower Yangtze fold belt at ca. $142 \mathrm{Ma}$ and ca. $131 \mathrm{Ma}$, respectively, were emplaced by a permissive mechanism through vertical to sub-vertical injection.

(4)

The NE-SW striking tension gashes indicate that the Lower Yangtze area experienced a NW-SE extension, which accommodated the emplacement of the Qingyang-Jiuhua massif. This deformation is consistent with the Cretaceous extensional tectonics already described in the SCB. However, the NW-SE extensional stretching was rather moderate, probably equal to the width of the tension gashes, as ductile deformation in these plutons and the country rock is weak.

\section{Acknowledgements}

The first author benefited from a scholarship of the Sino-Euro Joint Doctoral Promotion Program (DPP) of Chinese Academy of Sciences for his Ph.D stay in ISTO (France). We appreciate the constructive comments provided by Prof. W. G. Ernst and another anonymous reviewer to improve this manuscript. This study was funded by NSFC (41225009), The Project of Major State Special Research on the Petroleum form National Development and Reform Commissio Grant No. 2011ZX05008-001, the Innovative Project of the Chinese Academy of Sciences (Grant No. KZCX1-YW-15-1), the Major National Science and Technology Project (No. 2011ZX05008-001), and the grant of Ministry of Land and Resources (201211024-04).

\section{References}

AHBGMR, 1987. Regional geology of Anhui Province. Geological plublishing house, Beijing, China.

\section{J.L. Anderson, D.R. Smith}

The effects of themperature and $\mathrm{f}(\mathrm{O} 2)$ on the Al-in-hornblende barometer American Mineralogist, 80 (1995), pp. 549-559 
A. Aranguren, J. Cuevas, J.M. Tubia, T. Roman-Berdiel, A. Casas-Sainz, A. Casas-Ponsati

Granite laccolith emplacement in the Iberian arc: AMS and gravity study of the La Tojiza pluton (NW Spain)

Journal of the Geological Society, 160 (2003), pp. 435-445

C. Bassin, G. Laske, G. Masters

The current limits of resolution for surface wave tomography in North America

EOS Trans AGU, 81 (2000), p. F897

N. Charles, M. Faure, Y. Chen

The Montagne Noire migmatitic dome emplacement (French Massif Central): new insights from petrofabric and AMS studies

Journal of Structural Geology, 31 (2009), pp. 1423-1440

J. Charvet, L.S. Shu, Y.S. Shi, L.Z. Guo, M. Faure

The building of south China: collision of Yangzi and Cathaysia blocks, problems and tentative answers

Journal of Southeast Asian Earth Sciences, 13 (1996), pp. 223-235

J.F. Chen, G. Yu, G. Yang, S.H. Yang

A geochronological framework of Late Mesozoic magmatism and metallogenesis in the Lower Yangtze valley, Anhui Province

Anhui Geology, 15 (2005), pp. 161-169

J.F. Chen, T.X. Zhou, K.A. Foland

${ }^{40} \mathrm{Ar} /{ }^{39} \mathrm{Ar}$ and $\mathrm{Rb}-\mathrm{Sr}$ geochronology of the Qingyang batholith, Anhui Province, China

Geochemistry, 4 (1985), pp. 220-235

\section{B.L. Cong, Q.C. Wang}

The new advantage in ultrahigh pressure metamorphic region in Dabie-Sulu Mountains

Chinese Science Bulletin, 44 (1999), pp. 1127-1141

Chu, Y., Lin, W., 2014. Phanerozoic polyorogenic deformation in southern Jiuling massif, northern South China block: constraints from structural analysis and geochronogy. Journal of Asian Earth Sciences 86, 117-130. 
Continental subduction and exhumation of UHP rocks. Structural and geochronological insights from the Dabieshan (East China)

Lithos, 70 (2003), pp. 213-241

M. Faure, W. Lin, L.S. Shu, Y. Sun, U. Scharer

Tectonics of the Dabieshan (eastern China) and possible exhumation mechanism of ultra high-pressure rocks

Terra Nova, 11 (1999), pp. 251-258

M. Faure, W. Lin, Y. Sun

Doming in the southern foreland of the Dabieshan (Yangtse block, China)

Terra Nova, 10 (1998), pp. 307-311

M. Faure, Y. Sun, L. Shu, P. Monie, J. Charvet

Extensional tectonics within a subduction-type orogen. The case study of the Wugongshan dome (Jiangxi Province, southeastern China)

Tectonophysics, 263 (1996), pp. 77-106

\section{S.A. Gilder, G.R. Keller, M. Luo, P. Goodell}

Eastern Asia and the western Pacific timing and spatial distribution of rifting in China

Tectonophysics, 197 (1991), pp. 225-243

P.C. Goodell, S. Gilder, X. Fang

A preliminary description of the Gan-Hang failed rift, southeastern China Tectonophysics, 197 (1991), pp. 245-255

B.R. Hacker, L. Ratschbacher, L. Webb, T. Ireland, D. Walker, D. Shuwen

$\mathrm{U} / \mathrm{Pb}$ zircon ages constrain the architecture of the ultrahigh-pressure QinlingDabie Orogen, China

Earth and Planetary Science Letters, 161 (1998), pp. 215-230

J.M. Hammarstrom, E.A. Zen

Aluminum in hornblende - an empirical igneous geobarometer

American Mineralogist, 71 (1986), pp. 1297-1313

L.S. Hollister, G.C. Grissom, E.K. Peters, H.H. Stowell, V.B. Sisson

Confirmation of the empirical correlation of $\mathrm{Al}$ in hornblende with pressure of solidification of calc-alkaline plutons 
American Mineralogist, 72 (1987), pp. 231-239

W. Ji, W. Lin, Y. Shi, Q. Wang, Y. Chu

Structure and evolution of the Early Cretaceous Dabieshan metamorphic core complex

Chinese Journal of Geology, 46 (2011), pp. 161-180

\section{A. Joly, M. Faure, G. Martelet, Y. Chen}

Gravity inversion, AMS and geochronological investigations of syntectonic granitic plutons in the southern part of the Variscan French Massif Central Journal of Structural Geology, 31 (2009), pp. 421-443

B.E. Leake, A.R. Woolley, C.E.S. ARPS, W.D. Birch, M.C. Gilbert, J.D. Grice, F.C. Hawthorne, A. Kato, H.J. Kisch, V.G. Krivovichev, K. Linthout, J. Laird, J. Mandarino, W.V. Maresch, E.H. Nickel, N.M.S. Rock

Nomenclature of amphiboles - report of the subcommittee on amphiboles of the international mineralogical association commission on new minerals and mineral names

European Journal of Mineralogy, 9 (1997), pp. 623-651

J.W. Li, X.F. Zhao, M.F. Zhou, C.Q. Ma, Z.S. De Souza, P. Vasconcelos

Late Mesozoic magmatism from the Daye region, eastern China: $\mathrm{U}-\mathrm{Pb}$ ages, petrogenesis, and geodynamic implications

Contributions to Mineralogy and Petrology, 157 (2009), pp. 383-409

S. Li, G. Zhao, G. Zhang, X. Liu, S. Dong, Y. Wang, X. Liu, Y. Suo, L. Dai, C. Jin

Not all folds and thrusts in the Yangtze foreland thrust belt are related to the Dabie Orogen: insights from Mesozoic deformation south of the Yangtze River

Geological Journal, 45 (2010), pp. 650-663

X.H. Li, W.X. Li, Z.X. Li, C.H. Lo, J. Wang, M.F. Ye, Y.H. Yang

Amalgamation between the Yangtze and Cathaysia Blocks in South China: constraints from SHRIMP U-Pb zircon ages, geochemistry and $\mathrm{Nd}-\mathrm{Hf}$ isotopes of the Shuangxiwu volcanic rocks

Precambrian Research, 174 (2009), pp. 117-128

X.H. Li, W.X. Li, X.C. Wang, Q.L. Li, Y. Liu, G.Q. Tang, Y.Y. Gao, F.Y. Wu

SIMS U-Pb zircon geochronology of porphyry $\mathrm{Cu}-\mathrm{Au}-(\mathrm{Mo})$ deposits in the Yangtze River Metallogenic Belt, eastern China: magmatic response to early Cretaceous lithospheric extension

Lithos, 119 (2010), pp. 427-438 
W. Lin, M. Faure, P. Monie, U. Scharer, L.S. Zhang, Y. Sun

Tectonics of SE China: new insights from the Lushan massif (Jiangxi Province) Tectonics, 19 (2000), pp. 852-871

W. Lin, M. Faure, Y. Sun, L.S. Shu, Q.C. Wang

Compression to extension switch during the Middle Triassic orogeny of Eastern China: the case study of the Jiulingshan massif in the southern foreland of the Dabieshan

Journal of Asian Earth Sciences, 20 (2001), pp. 31-43

\section{W. Lin, Y.H. Shi, Q.C. Wang}

Exhumation tectonics of the HP-UHP orogenic belt in Eastern China: new structural-petrological insights from the Tongcheng massif, Eastern Dabieshan Lithos, 109 (2009), pp. 285-303

M.X. Ling, F.Y. Wang, X. Ding, Y.H. Hu, J.B. Zhou, R.E. Zartman, X.Y. Yang, W.D. Sun

Cretaceous ridge subduction along the Lower Yangtze river belt, Eastern China

Economic Geology, 104 (2009), pp. 303-321

J. Mao, G. Xie, C. Duan, F. Pirajno, D. Ishiyama, Y. Chen

A tectono-genetic model for porphyry-skarn-stratabound $\mathrm{Cu}-\mathrm{Au}-\mathrm{Mo}-\mathrm{Fe}$ and magnetite-apatite deposits along the Middle-Lower Yangtze River Valley, Eastern China

Ore Geology Reviews, 43 (2011), pp. 294-314

M. Mattauer, P. Matte, J. Malavieille, P. Tapponnier, H. Maluski, Z.Q. Xu, Y.L. Lu, Y.Q. Tang

Tectonics of the Qinling belt - buildup and evolution of eastern Asia

Nature, 317 (1985), pp. 496-500

J.L. Mercier, M.J. Hou, P. Vergely, Y.M. Wang

Structural and stratigraphical constraints on the kinematics history of the southern Tan-Lu fault zone during the mesozoic Anhui Province, China

Tectonophysics, 439 (2007), pp. 33-66

\section{J.S. Myers}

Cauldron subsidence and fluidization: mechanisms of intrusion of coastal batholith of Peru into its own volcanic ejecta 
Geological Society of America Bulletin, 86 (1975), pp. 1209-1220

W.S. Pitcher

The nature, ascent and emplacement of granitic magmas

Journal of the Geological Society, 136 (1979), pp. 627-662

J.C. Schmid, L. Ratschbacher, B.R. Hacker, I. Gaitzsch, S.W. Dong

How did the foreland react? Yangtze foreland fold-and-thrust belt deformation related to exhumation of the Dabie Shan ultrahigh-pressure continental crust (eastern China)

Terra Nova, 11 (1999), pp. 266-272

R. Schmid, T. Ryberg, L. Ratschbacher, A. Schulze, L. Franz, R. Oberhänsli, S. Dong

Crustal structure of the eastern Dabie Shan interpreted from deep reflection and shallow tomographic data

Tectonophysics, 333 (2001), pp. 347-359

M.W. Schmidt

Amphibole composition in tonalite as a function of pressure - an experimental calibration of the Al-in-hornblende barometer

Contributions to Mineralogy and Petrology, 110 (1992), pp. 304-310

L.S. Shu, M. Faure, S.Y. Jiang, Q. Yang, Y.J. Wang

SHRIMP zircon $\mathrm{U}-\mathrm{Pb}$ age, litho- and biostratigraphic analyses of the Huaiyu Domain in South China - evidence for a Neoproterozoic orogen, not Late

Paleozoic-Early Mesozoic collision

Episodes, 29 (2006), pp. 244-252

R.H. Sibson

Continental fault structure and the shallow earthquake source

Journal of the Geological Society, 140 (1983), pp. 741-767

J.Y. Talbot, M. Faure, Y. Chen, G. Martelet

Pull-apart emplacement of the Margeride granitic complex (French Massif

Central). Implications for the late evolution of the Variscan orogen

Journal of Structural Geology, 27 (2005), pp. 1610-1629

Talbot, J.Y., Chen, Y., Faure, M., 2005b. A magnetic fabric study of the Aigoual-Saint Guiral-Liron granite pluton (French Massif Central) and relationships with its associated dikes. Journal of Geophysical Research-Solid, Earth, vol. 110. 
J.Y. Talbot, G. Martelet, G. Courrioux, Y. Chen, M. Faure

Emplacement in an extensional setting of the Mont Lozere-Borne granitic complex (SE France) inferred from comprehensive AMS, structural and gravity studies Journal of Structural Geology, 26 (2004), pp. 11-28

P. Turrillot, M. Faure, G. Martelet, Y. Chen, R. Augier

Pluton-dyke relationships in a Variscan granitic complex from AMS and gravity modelling. Inception of the extensional tectonics in the South Armorican Domain (France)

Journal of Structural Geology, 33 (2011), pp. 1681-1698

Q. Wang, D.A. Wyman, J.F. Xu, Z.H. Zhao, P. Jian, X.L. Xiong, Z.W. Bao, C.F. Li, Z.H. Bai

Petrogenesis of Cretaceous adakitic and shoshonitic igneous rocks in the Luzong area, Anhui Province (eastern China): implications for geodynamics and $\mathrm{Cu}-\mathrm{Au}$ mineralization

Lithos, 89 (2006), pp. 424-446

Y.S. Wang, B.W. Xiang, G.A. Zhu, D.Z. Jiang

Structural and geochronological evidence for Early Cretaceous orogen-parallel extension of the ductile lithosphere in the northern Dabie orogenic belt, East China Journal of Structural Geology, 33 (2011), pp. 362-380

Wei, W., Chen, Y., Faure, M., Shi, Y.H., Martelet, G., Hou, Q.L., Lin, W., Le Breton, N., Wang, Q.C., 2014. A multidisciplinary study on the emplacement mechanism of the Qingyang-Jiuhua Massif in Southeast China and its tectonic bearings. Part I: structural geology, AMS and paleomagnetism. Journal of Asian, Earth Sciences 86, 76-93.

F.Y. Wu, W.Q. Ji, D.H. Sun, Y.H. Yang, X.H. Li

Zircon $\mathrm{U}-\mathrm{Pb}$ geochronology and $\mathrm{Hf}$ isotopic compositions of the Mesozoic granites in southern Anhui Province, China

Lithos, 150 (2012), pp. 6-25

Y.B. Wu, J. Tang, S.B. Zhang, Z.F. Zhao

SHRIMP zircon $\mathrm{U}-\mathrm{Pb}$ dating for two episodes of migmatization in the Dabie orogen

Chinese Science Bulletin, 52 (2007), pp. 1836-1842 
Petrogenesis and tectonic implications of Late Mesozoic granites in the NE Yangtze Block, China: further insights from the Jiuhuashan-Qingyang complex Geological Magazine, 147 (2010), pp. 219-232 X.Q. Yu, L.L. Jiang, W. Xue, R.L. Qiu, J.G. Du, S.Q. Dai Identification and basic characteristics of the Anhui-Zhejiang-Jiangxi fault zone Earth Science Frontiers, 14 (2007), pp. 102-113

Q. Zhang, Y.I. Wang, J.W. jun, C.D. Li

Eastern China Plateau during the Late Mesozoic: evidence, problems and implication

Geologcal Bulletin of China, 27 (2008), pp. 1404-1430

G. Zhu, M.L. Niu, C.L. Xie, Y.S. Wang

Sinistral to Normal Faulting along the Tan-Lu Fault Zone: Evidence for Geodynamic Switching of the East China Continental Margin

Journal of Geology, 118 (2010), pp. 277-293

G. Zhu, C.L. Xie, W. Chen, B.W. Xiang, Z.Q. Hu

Evolution of the Hongzhen metamorphic core complex: evidence for early cretaceous extension in the eastern Yangtze craton, eastern China

Geological Society of America Bulletin, 122 (2010), pp. 506-516

Q.b. Zhu, K.G. Yang, Y. Wang

Extensional detachment and magmatism of the lushan metamorphic core complex: constraints from ${ }^{40} \mathrm{Ar} /{ }^{39} \mathrm{Ar}$ and U-Pb geochronology

Geotectonica et Metallogenia, 34 (2010), pp. 391-401 